\author{
Marzena Hajduk \\ Katedra Ekonomii \\ Politechnika Rzeszowska
}

\title{
Wdrażanie systemów zarządzania środowiskowego jako narzędzie proinnowacyjnego rozwoju polskich przedsiębiorstw na rynku Unii Europejskiej
}

Stosowana na całym świecie przez wiele lat polityka liberalna, na skutek swobody decydowania o wykorzystaniu zasobów środowiska przyrodniczego doprowadziła do degradacji otoczenia i wyczerpania zasobów. Nastawienie na maksymalizację zysku coraz częściej obraca się przeciwko przedsiębiorcom, którzy muszą zdać sobie sprawę ze społeczno-środowiskowych skutków swojej działalności. W ujęciu ekonomisty zanieczyszczenie środowiska stanowi rodzaj zakłócenia, dla konsumenta oznacza ubytek dobrobytu, dla producenta zaś może być przyczyną wzrostu jednostkowych kosztów produkcji (Łuszczyk 2000). W tym kontekście układ społeczeństwo - środowisko - gospodarka to nierozerwalny układ oddziaływań (na zasadzie sprzężeń zwrotnych), które właściwie używane generują efekt synergii, a wykorzystywane niewłaściwie prowadzą do destrukcji. Bierna i zachowawcza postawa wielu polskich przedsiębiorców, którzy w strategiach swoich firm nie uwzględniają zagadnień środowiskowych, skutkuje tym, że konkurencja jest postrzegana nie jako szansa i wyzwane, lecz jako zagrożenie. Nastawienie na przetrwanie, a nie na rozwój, naśladowanie innych na zasadzie dokładnego kroczenia „Śladami wydeptanymi w śniegu”, to typowe działania przedsiębiorców, których S. Kwiatkowski (2000) zalicza do grupy small businessu. Przedsiębiorcy zaliczeni do tej sfery nie podejmują ekspansywnych działań, które pozwoliłyby wyprzedzić konkurentów i osiagnać sukces. Mimo to ,zadowoleni z bieżących sukcesów, zmęczeni, zabiegani, wierzą, że jakoś to będzie, że najważniejsze jest przetrwać jeszcze jeden dzień, zdobyć jeszcze jedno zamówienie, kupić taniej i sprzedać drożej (...). Czasami inwestują i cieszą się, że ich firma rośnie. I kręcą się w kółko małego przedsięwzięcia (...). I zazwyczaj tacy mali pozostają, nigdy nie zadają sobie trudu, aby zrozumieć podstawową zasadę biznesu: przeciętność oznacza powolne staczanie się po równi pochyłej, a na równi pochyłej dominującym jest ruch w dół" (Obłój 1995). W ich przypadku brak możliwości konkurowania prowadzi do utraty pozycji rynkowej, podporządkowania się dominacji silniejszych - otwartych na podejmowanie ryzyka i wdrażanie innowacyjnych rozwiązań. Wszystko to oznacza wyeliminowanie z gry rynkowej w przyszłości, z czego znaczna część polskich przedsiębiorców wydaje się nie zdawać sobie sprawy.

Jak pokazują wyniki badań przeprowadzonych w Stanach Zjednoczonych, prawie 1/3 ankietowanych przedsiębiorstw traktuje problemy ekologiczne jak problemy kluczowe, a $60 \%$ określa je jako ważne. Co więcej, 70\% badanych uważa, że znaczenie środowiska będzie rosło (Sroka 1998). Wymiar środowiskowy stał się jednym z trzech podstawowych wymiarów nowej strategii firm Corporate Social Responsibility, propagowanej przez Komisję Europejską i ONZ. Wymiar ten jest coraz częściej rozważany w kontekście oceny pozycji firmy na rynku, m.in. jest uwzględniany przez międzynarodowe indeksy (np. Dow Jones Sustainability Indexes) 
(Lewicka-Strzałecka 2004). Współczesne zarządzanie nie traktuje ochrony środowiska wyłącznie w kategorii dodatkowego kosztu; uważa ją za istotny czynnik promocji przedsiębiorstwa (Penc 1995). Według D.B. Yoffie i M. Kwaka, małe przedsiębiorstwa mogą odnosić sukcesy rynkowe, jeśli zastosują „strategię judo" polegającą na podejmowaniu inicjatywy w konfrontacji z silniejszymi konkurentami - zamiast defensywy. Pozwoli to na przynoszącą wymierne korzyści rywalizację, która jednocześnie umożliwi unikanie bezpośredniej konfrontacji nierównych sił. Szybkość działania, kreatywność i coraz to nowe umiejętności pozwolą wygrać z siłą konkurenta (Yoffie, Kwak 2002).

Wdrażanie systemowo uporządkowanego mechanizmu budowania, rozwijania i promowania wynalazczych idei, który pozwoli sprawnie i elastycznie reagować na aktualne wyzwania rynkowe (w sferze zarówno produktów i procesów, jak i aspektów organizacyjnych), jest szczególnie ważne w kontekście ekologizacji procesu zarządzania sektora MŚP. Ekologizacja polega na odmiennym niż do tej pory stylu gospodarowania. Stylu, który uwzględnia cele rozwoju zrównoważonego (ekorozwoju) na każdym etapie funkcjonowania organizacji, sprzyja ochronie środowiska przed degradacją i zapewnia wysoką jakość życia. Jak zauważa A. Chodyński (1999), ekologiczność obejmuje:

- ,potrzeby klientów (w związku z podwyższeniem poziomu życia i zmian popytu, ze szczególnym uwzględnieniem ekologii),

- wymagania społeczeństw i ich rządów (w związku z wyczerpywaniem zasobów naturalnych i zanieczyszczeniem środowiska przyrodniczego),

- wymagania pracowników (w związku z zagrożeniem zdrowia i życia),

- wymagania przedsiębiorstw na konkurencyjnym rynku (w związku z proekologiczną polityką państwa lub jako element strategii marketingowej). Ekologiczność odnosi się również do jakości wyrobów i procesów wytwarzania (...). Można przyjąć, że tworzy się nowa jakość określana jako ,jakość ekologiczna”.

Jednym z elementów realizacji założeń rozwoju zrównoważonego jest wdrażanie w polskich przedsiębiorstwach systemów zarządzania środowiskowego (SZŚ). W literaturze przedmiotu pojawiają się zróżnicowane podejścia do definiowania zarządzania środowiskowego (tab. 1).

Systemy zarządzania środowiskowego można podzielić na dwie grupy. Pierwszą stanowią tzw. systemy niecertyfikowane (niesformalizowane), np. wdrożony w firmie Ekomaping: Ekoprofit - system gospodarki odpadami. Te systemy, określane często jako systemy czystszej produkcji, kładą szczególny nacisk na ograniczanie powstawania zanieczyszczeń u źródła, czyli na etapie ich powstawania zarówno w procesie produkcyjnym, jak i podczas całego życia wyrobu. Pozwala to przedsiębiorstwom osiagnąć dodatkowy efekt ekonomiczny w postaci redukcji kosztów (np. poprzez zmniejszenie opłat z tytułu korzystania ze środowiska dzięki opracowaniu i wdrożeniu metod racjonalnej gospodarki surowcami). Czystsza produkcja nakłada jednak na firmy obowiązek ,,przedłużonej odpowiedzialności” za produkt i jego wpływ (podczas całego cyklu życia) na środowisko przyrodnicze.

Druga grupę stanowią systemy formalne, tzw. standardowe systemy zarządzania środowiskowego, zgodne z międzynarodowymi standardami, np. ISO 14001 i EMAS.

Oto najistotniejsze cechy systemu zarządzania środowiskowego według normy ISO 14001:

- dobrowolność podejmowania decyzji o wdrażaniu systemu zarządzania środowiskowego w różnych typach organizacji (nie tylko w przedsiębiorstwach) i zintegrowanie go z ogólnym systemem zarządzania przedsiębiorstwem (Mikuła 2000);

- wymaganie dążenia do ciągłej poprawy (analizując czynniki, m.in. ekonomiczne, ekologiczne, społeczne, prawne itp., organizacja sama określa obszary, w których będzie się doskonalić), zgodnie z ideą cyklu Deminga; 
- zobowiązanie do zaangażowania pracowników we wdrażanie i funkcjonowanie systemu zarządzania środowiskowego na wszystkich szczeblach organizacji (z uwzględnieniem szczególnej roli naczelnego kierownictwa);

- zobowiązanie do sformułowania polityki środowiskowej, celów i programu działania;

- uwypuklenie szczególnej roli wewnętrznego systemu kontroli w celu osiagnięcia założonych celów;

- zobowiązanie organizacji do spełniania wymogów prawnych dotyczących ochrony środowiska.

Tab. 1. Interpretacje definicji zarządzania środowiskowego według wybranych autorów

\begin{tabular}{|l|l|}
\hline Według & $\begin{array}{l}\text { Zarządzanie środowiskowe zawiera aspekty ogólnej funkcji zarządzania, obej- } \\
\text { mujące opracowanie, wdrożenie i realizację polityki i celów środowiskowych } \\
\text { każdej organizacji. B. Poskrobko zwraca uwage, że zarządzanie środowiskowe } \\
\text { jest znormalizowane i związane jedynie z jednostkami organizacyjnymi. Fakt } \\
\text { ten jest szczególnie istotny w konfrontacji pojęcia zarządzania środowiskowego } \\
\text { z pojęciem szerszym, jakim jest zarządzanie środowiskiem, gdzie obiektem zain- } \\
\text { teresowania jest triada: środowisko - społeczeństwo - gospodarka (Poskrobko } \\
1999,2003) .\end{array}$ \\
\hline $\begin{array}{l}\text { Według } \\
\text {-Dziubińskiej }\end{array}$ & $\begin{array}{l}\text { Zarządzanie środowiskowe to potencjał wiedzy, umiejętności i technik zarzą- } \\
\text { dzania przedsiębiorstwem, które pozwalają na uzyskanie wysokiej efektywno- } \\
\text { ści ekonomicznej produkcji dóbr i usług oraz minimalne obciążenie środowiska } \\
\text { przyrodniczego (Burchard-Dziubińska 2000). }\end{array}$ \\
\hline $\begin{array}{l}\text { Według } \\
\text { P. Grudowskiego }\end{array}$ & $\begin{array}{l}\text { Zarządzanie środowiskowe to wszelkie działania przedsiębiorstwa, które mają } \\
\text { lub w przyszłości mogą mieć wpływ na środowisko. Działania te mają na celu } \\
\text { tworzenie takich uwarunkowań działania przedsiębiorstwa, by mogło ono usta- } \\
\text { wicznie i permanentnie zmniejszać negatywny wpływ na środowisko przyrodni- } \\
\text { cze, w którym funkcjonuje (Gradowski 2003). }\end{array}$ \\
\hline $\begin{array}{l}\text { Według normy } \\
\text { ISO 14001:1996 }\end{array}$ & $\begin{array}{l}\text { System zarządzania środowiskowego - część ogólnego systemu zarządzania, } \\
\text { która obejmuje strukturę organizacyjna, planowanie, odpowiedzialność, zasady } \\
\text { postępowania, procedury, procesy i środki potrzebne do opracowania, wdraża- } \\
\text { nia, realizowania, przeglądu i utrzymania polityki środowiskowej. }\end{array}$ \\
\hline ISO 14001:2004 & $\begin{array}{l}\text { System zarządzania środowiskowego - czę́ć systemu zarządzania organizacji } \\
\text { wykorzystana do ustanowienia i wdrożenia polityki środowiskowej oraz do za- } \\
\text { rządzania aspektami środowiskowymi. }\end{array}$ \\
\hline
\end{tabular}

Źródło: opracowanie własne

Posiadanie certyfikatu zgodności z ISO 14001 nie oznacza, że organizacja oddziałuje na środowisko w znikomym stopniu. Bardzo często jej oddziaływanie jest duże. Certyfikat jest potwierdzeniem zidentyfikowania problemów (aspektów środowiskowych) związanych z szeroko rozumianą działalnością organizacji i jej skutkami, co przekłada się na przygotowanie programu ograniczenia oddziaływania na środowisko i ciagłego doskonalenia, szczególnie pod względem przestrzegania przepisów prawnych dotyczących ochrony środowiska.

Liczba krajowych firm, które wprowadzają systemy zarządzania środowiskowego, rośnie $\mathrm{z}$ roku na rok (ryc. 1). 
Ryc. 1. Liczba certyfikatów ISO 14001 przyznanych w Polsce w latach 1997-2005

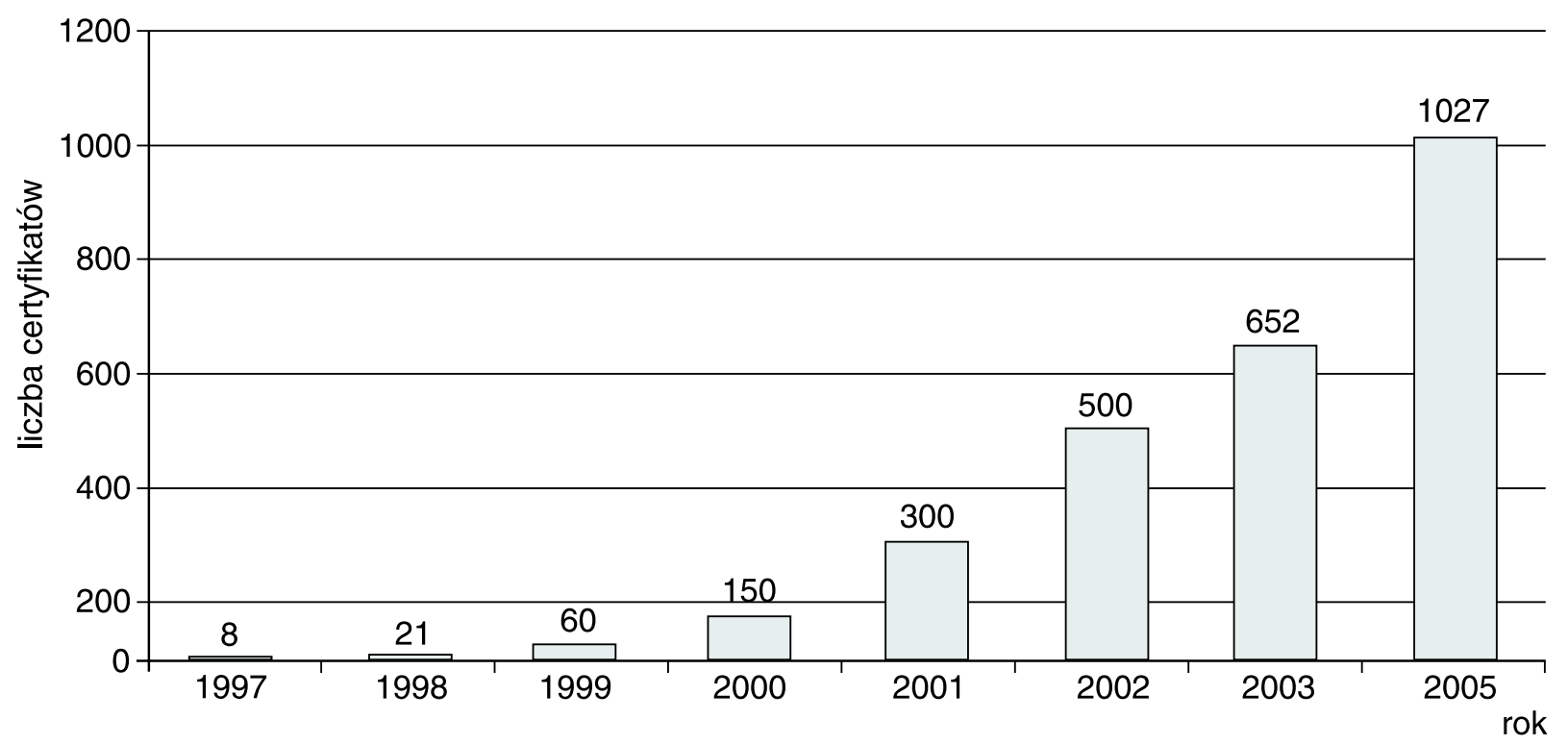

Źródło: na podstawie www.eko-net.pl

W 1999 r. takich przedsiębiorstw było zaledwie 30, w 2002 r. już 400, w lutym 2004 r. - około 670 (Pochyluk, 2004). 8.10.2005 r. orientacyjna liczba organizacji posiadających certyfikat zgodności z normą ISO 14001 wynosiła w Polsce $1027^{1}$. Liczba przedsiębiorstw posiadających certyfikat zgodności z normą ISO 14001 na świecie na końcu 2003 r. przekroczyła 61 tys., a w kwietniu 2005 r. $-88800^{2}$ (ryc. 2).

Ryc. 2. Liczba certyfikatów zgodności z ISO 14001 w wybranych krajach (kwiecień 2005 r.)

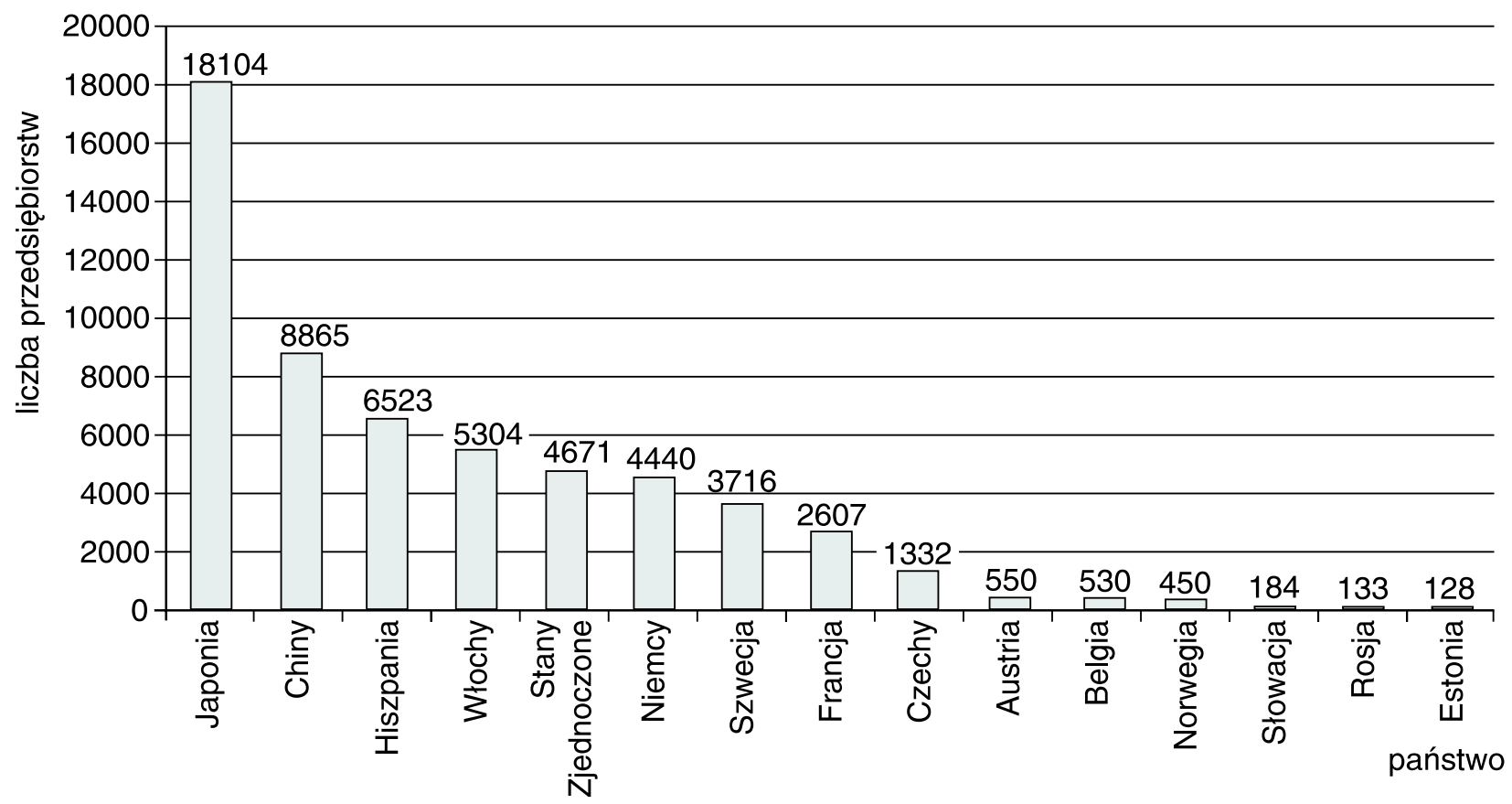

Źródło: opracowanie na podstawie: http://www.ecology.or.jp/isoworld/english/analy14k.htm, 9.10.2005 r.

\footnotetext{
${ }^{1}$ www.eko-net.pl

${ }^{2} \mathrm{http} / / / \mathrm{www}$. ecology.or.jp/isoworld/english/analy14k.htm.
} 
Rejestr organizacji spełniających wymogi europejskiego systemu ekozarządzania i audytu EMAS w kwietniu 2005 r. zawierał 4195 przedsiębiorstw³ (ryc. 3). Należy pamiętać, że dane o liczbie certyfikatów zgodności z ISO 14001 (liczba certyfikacji według ISO 14001 i zatwierdzeń według EMAS w wybranych krajach), wydanych zarówno w Polsce, jak i na świecie, mają charakter szacunkowy. Liczba ta nie jest dokładnie kontrolowana, gdyż nie istnieje żaden formalny mechanizm przekazywania informacji o uzyskanych certyfikatach.

Ryc. 3. Liczba firm w wybranych krajach Unii Europejskiej zarejestrowanych w systemie EMAS

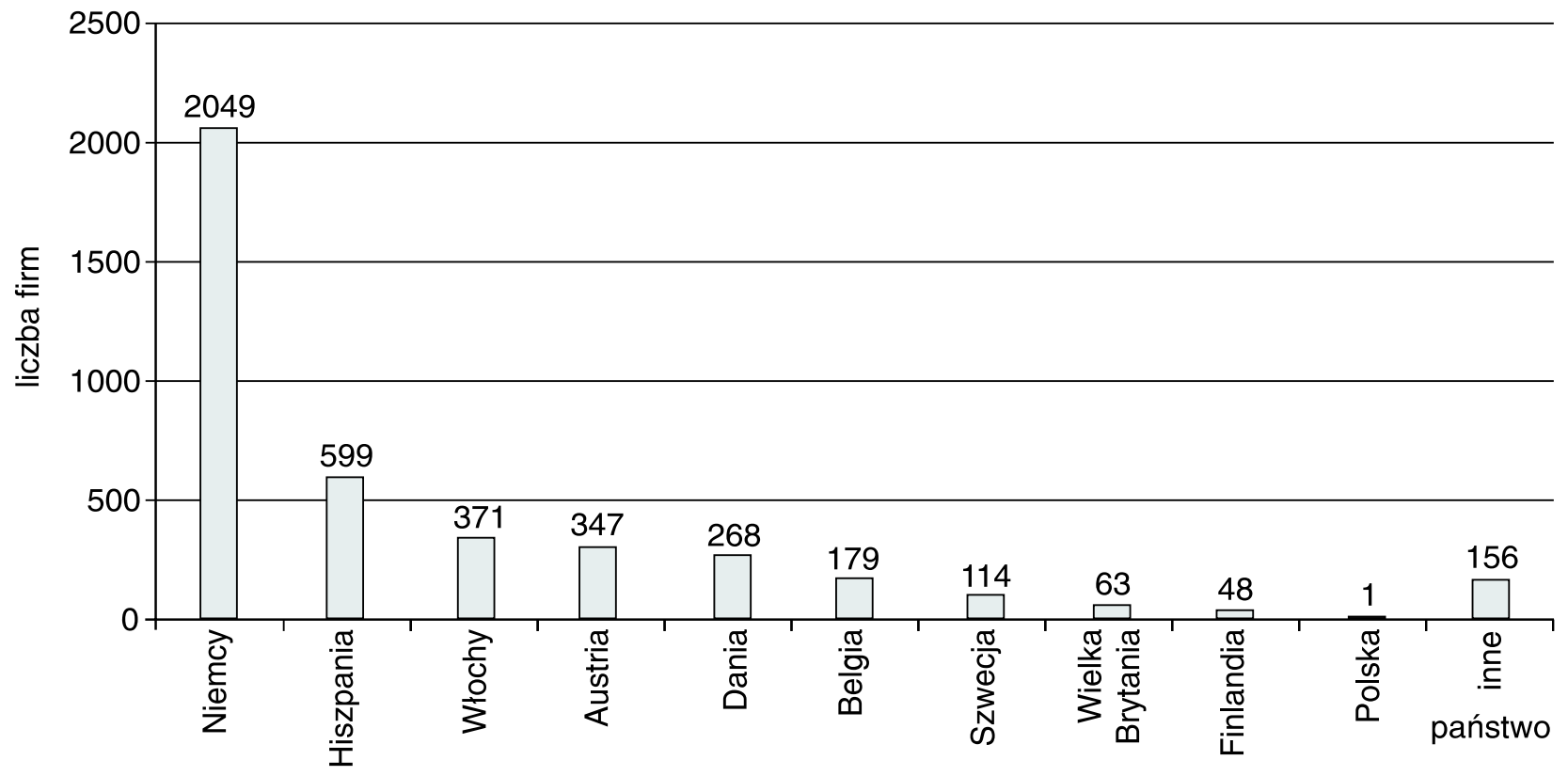

Źródło: opracowanie na podstawie: http://www.ecology.or.jp/isoworld/english/analy14k.htm.

6.10.2005 r. Elektrownia Opole $\mathrm{SA}^{4}$ jako pierwsza firma w Polsce uzyskała wpis do wojewódzkiego rejestru organizacji spełniających wymogi europejskiego systemu ekozarządzania i audytu EMAS. W związku z tym uzyskała znaczącą przewagę na rynku.

Do najważniejszych korzyści wynikających z wdrożenia w przedsiębiorstwie sformalizowanych systemów zarządzania środowiskowego należy zaliczyćs

1. korzyści wewnętrzne:

- zapewnienie przestrzegania przepisów środowiskowych - uporządkowanie stanu formalno-prawnego;

- podniesienie jakości i efektywności szkolenia w zakresie ochrony środowiska - zwiększenie świadomości ekologicznej na wszystkich szczeblach organizacji;

- prowadzenie racjonalnej gospodarki odpadowej;

- obniżenie stawek ubezpieczenia firmy od ryzyka ekologicznego;

- zmniejszenie liczby personelu środowiskowego;

- oszczędność materiałów, surowców, energii;

- zwiększenie bezpieczeństwa na stanowiskach pracy;

${ }^{3} \mathrm{http}: / /$ www.ecology.or.jp/isoworld/english/analy14k.htm.

${ }^{4}$ www.eko-net.pl

${ }^{5}$ Opracowanie własne na podstawie www.pfiso14000.org.pl ankiety S. Bukowickiej pt.: Oczekiwane korzyści z wdrożenia Systemu Zarządzania Środowiskiem [porównaj:] A. Matuszak-Flejszman, Jak skutecznie wdrożyć system zarzqdzania środowiskowego wedtug normy ISO 14001, Poznań 2001. 
- zmniejszenie zobowiązań środowiskowych: opłat, odszkodowań itp., w tym zmniejszenie ryzyka odpowiedzialności karnej;

- złagodzenie obciążenia wynikającego z przepisów środowiskowych w przyszłości;

- racjonalna gospodarka surowcowa, wodna i ściekowa;

- spadek ryzyka oraz zapobieganie incydentom środowiskowym - zmniejszenie prawdopodobieństwa wystąpienia sytuacji awaryjnych i wypadków w firmie dzięki wcześniejszemu zidentyfikowaniu potencjalnych zagrożeń i wprowadzenie rozwiązań zapobiegających takim zdarzeniom (wpłynie to na właściwe postępowanie w razie wystapienia incydentu środowiskowego);

- zwiększenie wydajności i efektywności gospodarowania;

- wzrost samokontroli i odpowiedzialności pracowników;

- obniżenie kosztów wytwarzania przy utrzymaniu jakości;

- zwiększenie innowacyjności firmy;

- efektywna alokacja zasobów;

2. korzyści zewnętrzne:

- zacieśnienie stosunków ze społecznością lokalną;

- demonstrowanie poprawy działan środowiskowych na zewnątrz w celu poprawy wizerunku firmy;

- zwiększenie konkurencyjności firmy na rynku (w kraju i za granica);

- zwiększenie zaufania władz lokalnych i inspekcji ochrony środowiska;

- ochrona zasobów przyrody: wody, gleby, powietrza, fauny i flory;

- zwiększenie zaufania konsumentów/utrzymanie klientów lojalnych/zyskanie nowych odbiorców;

- rozszerzony dostęp do funduszy pomocowych i dogodnych kredytów bankowych;

- lepszy wizerunek firmy, a tym samym silniejsza pozycja negocjacyjna;

- podniesienie wartości firmy w oczach inwestorów/akcjonariuszy;

- łatwiejsze otrzymanie pozwoleń, zezwoleń, licencji, pierwszeństwo w niektórych przetargach publicznych itd.

Firmy wdrażające systemy zarządzania środowiskowego można zaliczyć do firm promujących innowacje. Zgodnie z założeniami P. Druckera (1992), reagują one na nieoczekiwane zdarzenia, zwłaszcza na porażki. Starają się znaleźć w nich źródło nowych rozwiązań. Wszyscy pracownicy w takich firmach wiedza, że innowacje wynikają z działań każdego pracownika. Wszyscy są otwarci na zmiany, pewne ryzyko i ciągłe doskonalenie w taki sposób, aby odpowiedzieć na wymagania zmieniającego się otoczenia - zwłaszcza na coraz większe i szybsze zmiany w strukturze przemysłu czy strukturze rynku, wywołane chociażby czynnikami demograficznymi czy prawnymi, które mają znaczący wpływ na to, co będzie kupowane, przez kogo i w jakich ilościach. Wymaga to przyjęcia postawy przedsiębiorczej na każdym szczeblu działania organizacji. Ponadto wynika $z$ tego potrzeba takiego przeformułowania celów i zadań firmy, aby w jak najmniejszym stopniu negatywnie oddziaływać na środowisko. Od wszystkich pracowników firmy wymaga to więc ciagłego uczenia się i pozyskiwania nowej wiedzy, która - odpowiednio użyta - stanie się źródłem innowacji przynoszących zysk nie tylko przedsiębiorstwu, ale również całemu społeczeństwu i środowisku.

\section{Literatura}

1. Burchard-Dziubińska M., Zarzqdzanie ekologiczne w przedsiębiorstwie przemystowym [w:] Ekologizacja zarzadzania firma - zielone zarzqdzanie, S. Czaja (red.), Wydawnictwo AE we Wrocławiu, Wrocław 2000. 
2. Chodyński A., Jakość ekologiczna w strategii przedsiębiorstwa, „Problemy Jakości”, 11/1999.

3. Drucker P.F., Innowacje i przedsiębiorczość. Praktyka i zasady, PWE, Warszawa 1992.

4. Grudowski P., Jakość, środowisko i bhp w systemach zarzqdzania, Wydawnictwo AJG, Bydgoszcz 2003.

5. Kwiatkowski S., Przedsiębiorczość intelektualna, PWN, Warszawa 2000.

6. Lewicka-Strzałecka A., Proekologiczne postawy konsumenckie. Determinanta zrównoważonego rozwoju czy okazja do „,zielonego” biznesu?, „Prakseologia”, 144/2004.

7. Łuszczyk M., Problem zanieczyszczenia i ochrony środowiska w teorii ekonomii dobrobytu, „Ekonomia i Środowisko", 1/2000.

8. Matejuk J., Budowa konkurencyjności przedsiębiorstw w okresie transformacji, PRET S.A., Warszawa 2003.

9. Matuszak-Flejszman A., Jak skutecznie wdrożyć system zarzqdzania środowiskowego wedtug normy ISO 14001, Polskie Zrzeszenie Inżynierów i Techników Sanitarnych, Poznań 2001.

10. Mikuła J., System zarzqdzania środowiskowego [w:] Zarzadzanie jakościa, PK, Kraków 2000.

11. Obłój K., Strategia sukcesu firmy, PWE, Warszawa 1995.

12. Penc J., Strategie zarzadzania, Agencja Wydawnicza Placet, Warszawa 1995.

13. Piecuch T., Wpływ konkurencji na zachowanie MŚP, „Ekonomika i Organizacja Przedsiębiorstwa”, 9/2005.

14. Pochyluk R., Systemy zarzadzania środowiskowego wedtug ISO 14001 w pytaniach i odpowiedziach, „Problemy Ocen Środowiskowych”, 2 (25/2004).

15. Poskrobko B., System zarzqdzania ochrona środowiska w przedsiębiorstwie, „Ekonomia i Środowisko", 2/2004.

16. Poskrobko B., Teoretyczne i praktyczne podstawy nauki o zarzadzaniu środowiskiem, „Ekonomia i Środowisko", 1/2003.

17. Sroka K., Zielone alianse - nowa broń strategiczna przedsiębiorstw, „Ekonomika i Organizacja Przedsiębiorstwa", 11/1998.

18. Szydłowski M. (red.), Krajowy System Ekozarzadzania i Audytu (EMAS), Narodowa Fundacja Ochrony Środowiska, Warszawa 2004.

19. Yoffie D.B., Kwak M., Mastering Balance: How to Meet and Beat a Strong Opponent, „California Management Review", 2/2002.

20. www.eko-net.pl

21. www.pfiso14000.org.pl ankieta S. Bukowickiej pt.: Oczekiwane korzyści z wdrożenia Systemu Zarzqdzania Środowiskiem

22. http://www.ecology.or.jp/isoworld/english/analy14k.htm.

\section{The System of Environmental Management as a Tool for Promotional Support of EU Companies Development}

The treatment of environment as a part of economy led to foundation of an economical model, which destroys its natural system. The pro-ecological economy of the future enquires new attitudes, new paradigm; it requires as well relation change. The best way to improve the relation between the environment and companies is permanent seeking for innovation solutions. Economical rules should encourage to innovative but also pro-ecological solutions. EU-concept of creation of ecological environs and pro-innovative concept of clean production deserves for particular attention.

The efficient management with environment contributes to enhancement of environmental stand as well as to the rise of enterprise profits. The integrated system is supposed to decide in favor of presence of a firm on the EU market. 